\title{
Reflecting on 80 years of excellence
}

\begin{abstract}
A small group of members of the American Society for Clinical Investigation began chatting in 1916 about the possibility of launching a new biomedical research journal. By October 1924, they managed to make the idea a reality with the publication of the first issue of the Journal of Clinical Investigation. Our 80th birthday seems an appropriate time to reflect on the history of biomedical science as it has been played out on our pages.
\end{abstract}

We are concerned with the therapentics both of acute and of chronic diseases as well as with the health of the body and the relieffrom its disabilities during the years of its decline... Success in treating [diseases] can scarcely be expected until more knowledge has been accumulated of the normal mechanisms on a deviation from which they depend.

-Alfred E. Cohn, JCI inaugural editorial, October 1924 (1)

The Journal of Clinical Investigation (Figure 1) was originally conceived by a group of members of the American Society for Clinical Investigation (ASCI) who desired an alternative journal in which to publish their scientific contributions, a wish driven primarily by a dissatisfaction with the usual period of time - often a year or more - between article submission and publication. Also, unlike the abundance of journals biomedical researchers may choose from today, there were few options available to the physician-scientist in the early 1920s, and the group thought that recent advances in academic medicine warranted coverage in a new forum.

The JCI has had a rich and colorful history, made possible by numerous scientists who have served as editors-inchief (Table 1), members of the editorial committee, and reviewers and authors. Landmark papers (discussed in the retrospectives beginning on page 1034, in the highlights by the editors-in-chief beginning on page 1017, and below) have shifted paradigms and set trends. From the pages of the JCI one can obtain an incredible perspective on the evolution and maturation of biomedical science, and we hope to continue to provide the best place to present mechanistic and therapeutic advances. Here I've attempted to summarize 80 years of excellence in three parts: history, science, and landmarks.

Citation for this article: J. Clin. Invest. 114:1006-1016 (2004). doi:10.1172/JCI200423290.

\section{History of the $\mathrm{JCl}$}

Much has changed since the last time the Journal's history was contemplated, in $1959(2,3)$, but it is worthwhile to revisit the early days of the JCI to place more recent changes in context.

The early days: the 1920s through the 1940s. Since funding was necessary to launch such an ambitious endeavor, the ASCI originally approached the Rockefeller Institute for Medical Research (now known as Rockefeller University), envisaging the Journal as a companion to the Rockefeller-sponsored Journal of Experimental Medicine. The Institute granted funding in 1921, but the JCI only truly got underway in 1923 when G. Canby Robinson, the first editor-in-chief, pushed the ASCI and editors to officially launch the Journal.

It was proposed that the JCI would operate under the direction of a 15-member editorial committee that would handle the receipt and review of each article. In 1924, six men, with Robinson at the helm, launched the JCI and published a total of eleven research articles, seven in October and four in December. Obtaining ongoing funding to meet operating expenses proved a constant source of worry, and the JCI was nearly abandoned in 1934 because of a lack of funds - but not because of a lack of articles warranting publication. The financial shortfall was blamed on the number remained low: 278 in 1925, 550 in 1934, and only 900 in 1939 . Records suggest that the JCI survived in those years only by the continued generosity of the Rockefeller Institute. Editors also applied for grants, and in 1928, the ASCI increased annual dues from $\$ 3$ to $\$ 10$, with the $\$ 7$ increase deposited entirely into the JCI coffers. However, the $\$ 7$ increase netted each ASCI member a subscription to the JCI. This scheme continues today, but at a significantly higher cost (current dues for an active ASCI member are $\$ 190$ per annum, $\$ 95$ of which covers a subscription to the JCI). Over the years, other sources of income have been introduced to of subscriptions, which, though growing, offset the cost of nonprofit publication, but subscription revenues were important early on and remain so today (Figure 2). In 1931, the Chemical Foundation took over the JCI's business affairs and also injected further funding. However, in 1940, the Chemical Foundation divested itself of the JCI, and the editors had to find sources for alternate funds to avoid collapse. The 1940s saw the introduction of advertisements (see sidebar, Medicine Avenue: 80 years of advertising in the JCI), but only from so-called reputable advertisers. In practice, it is unlikely the editors ever refused advertisements.

Bolstered by advertising dollars and everincreasing submissions, the JCI continued through the war years and even obtained special funding to publish supplements, the first being a 23-paper focus on "Chemical, clinical and immunological studies on the products of human plasma fractionation” in July 1944.

In 1942, the editor-in-chief, James Gamble, made the biggest change in JCI's editorial policy since it had been established by seeking expert reviewers beyond the 15-person editorial committee to review articles submitted for consideration for publication. Thus began the policy of external peer review

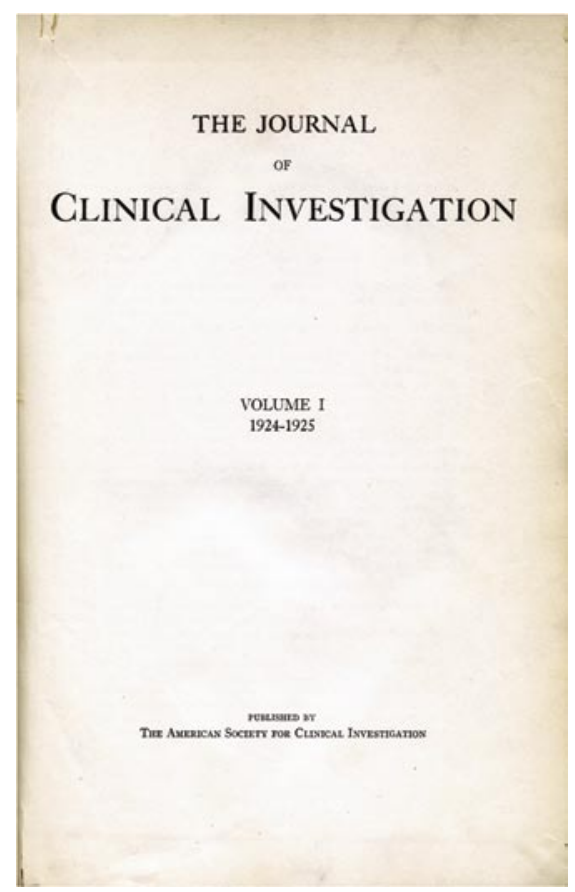

Figure 1

The first cover of the $\mathrm{JCl}$, October 20, 1924. 
Table 1

Editors-in-Chief

\section{Editor}

G. Canby Robinson

J. Harold Austen

John R. Paul

Randolph West

James L. Gamble

Eugene B. Ferris Jr.

Stanley E. Bradley

Philip K. Bondy

Arnold S. Relman

Paul A. Marks

DeWitt S. Goodman

Jean D. Wilson

Philip W. Majerus

Stuart Kornfeld

Thomas P. Stossel

Joseph Avruch

Bruce F. Scharschmidt

Ajit P. Varki

Paul A. Insel

Martin F. Kagnoff

Stephen J. Weiss

Andrew R. Marks of JCI articles. Such reviews were originally sought only from ASCI members, but the next editor-in-chief, Eugene B. Ferris Jr., also invited non-members to act as reviewers. In 1947, Ferris also began requiring authors to submit duplicate copies of their work to facilitate the critiques of two reviewers rather than one as had been previously required. Current policy still allows non-ASCI members to review articles - fewer than $10 \%$ of our referees are ASCI members - and we typically seek the opinions of three referees. Electronic submission and tracking of manuscripts, introduced in 1997, has made the review process more efficient, but acknowledgment should be made of the burdens both current and previous editors have carried: There were approximately 250-300 submissions per year in the 1940s; the first concrete statistics available record 336 submissions in 1953 and 417 in 1958. In 2003, the JCI received 3,045 new manuscripts for consideration (Figure 3). The ever-increasing submission numbers likely reflect the JCP's solid relevance to, and standing within, the global biomedical community.

The growth spurt: the 1950s through the 1970s. Apparently Ferris left the Journal in good shape when he turned it over to the next set of editors in 1952 since, by their own analysis, fairly little changed in terms of policy and operations (3). However, many modifications were made as the JCI matured. The 1960s precipitated an updating of the Journal's look: the cover was changed in 1960 - to show the table of contents
- and then again in 1968 - when the table of contents was removed. The first color figure appeared in 1963, but as the associated charges to the authors were rather high, printing of color histology was not the norm until the mid-1980s. In 1967, article layout changed for the first time since the switch from a one-column to a two-column format in 1935. The year 1965 brought a new $\$ 10$ per-page charge for each printed article (Figure 2), which has steadily increased as publication costs have increased in parallel (for more on the recent finances of the JCI, see ref. 4). The editorial that introduced this fee was accompanied by the words, "provided that research grants can bear this cost." It should be noted that the JCI has discounted, and continues to discount, the fee for scientists in developing countries and for authors unable to provide payment. In May 1967, the Journal was brought under the umbrella of Rockefeller University Press alongside the Journal of Experimental Medicine, the Journal of Cell Biology, and the Journal of General Physiology. This took the JCI back to its original roots. Rockefeller University Press continued to publish the Journal until January 1999, when publication was brought in house and the ASCI began its role as a publisher as well as an honor society.

Coeditors Paul Marks and DeWitt Goodman introduced the 3- to 4-page Concise Publications, meant to provide a home for important short reports, in January 1971. Concise Publications were continued until 1978, when editor-in-chief Philip Majerus replaced them with Rapid Publications. The editors pledged to return a decision on a Rapid within 2 weeks of receipt and, if the article was accepted, to publish it within 10-12 weeks of receipt. Rapids, altered somewhat from their original conception, are still in use today.

\section{Figure 2}

Annual subscription fees (shown in green for a full personal subscription) have traditionally been a major source of income. Author-paid page charges (blue) and submission fees (red) also contribute: the price of a 9-page black-and-white article is shown. Note that fees for color figures are not factored into the data presented and that the pricing scheme introduced in June 2003 charges per word and per figure rather than per page. Color pages once cost as much as $\$ 2,000$ each (in 1996) but are now much more affordable. Also note that for many years the price per page increased dramatically if more than 8 pages were required.

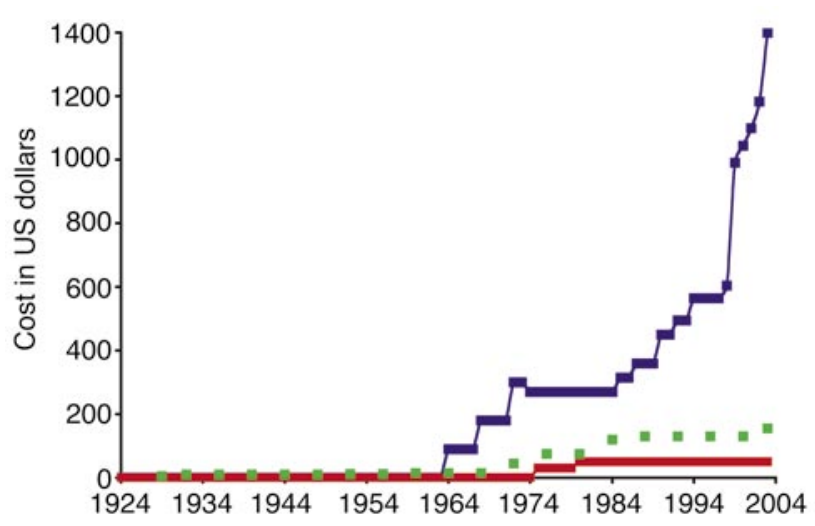




\section{Medicine Avenue: $\mathbf{8 0}$ years of advertising in the $\mathrm{JCI}$}

Medicine was perhaps the first product for which supply exceeded demand, and advertising sought to reverse this imbalance. Until the early 20th century, advertisements and store shelves were plagued with "patent medicines," a notorious array of pills, snake oil, and tonics, mostly ineffective and sometimes deadly, peddled for their alleged healing powers. However, beginning with the creation of the FDA in 1927, legal reform swept through the pharmaceutical industry. Examination of the advertisements appearing on JCI pages throughout its 80 -year history affords us the opportunity to reflect on the changing face of medical advertising and the evolution of biomedical research.

In 1941, advertisements first started appearing regularly in the JCI. Nutrition was of great interest in the 1940s; the world was engaged in war, and food was rationed. Black-and-white ads primarily featured amino acid supplements for diseases of malnutrition - a boom industry following rapid progress in the early 1920s in the isolation and synthesis of vitamins $\mathrm{D}, \mathrm{B} 1$, and $\mathrm{B} 2$.

It was not uncommon during wartime to see appeals to patriotism and references to politics. A 1943 advertisement for SMA brand infant formula reads: "Daddy doesn't know me very well, on account of he's overseas and hasn't seen me yet ... Mama says that he's all upset because our fats are rationed... The men in Washington are doing everything in their power to provide the folks who make S-M-A ... with enough cans, enough special fats ... Our government isn't going to let babies go without foods they need ... Doctor - this is America!”

A male figure brandishing a rifle in an advertisement for a pregnancy supplement demands that the reader be "On Guard" in order to "properly safeguard the two or more lives traveling together" (Figure 5). Such powerful imagery is unlikely to be associated with nutritional supplements for expectant mothers today.

Many ads of this period are early examples of testimonial advertising, labeling products as "Council accepted" or "accepted [by the] American Medical Association.” In step with the growth in popularity of evidence-based medicine, drug advertisements began incorporating bibliographic references from prestigious journals to reinforce their therapeutic claims. Reference to randomized trials is an important promotional strategy that continues today.
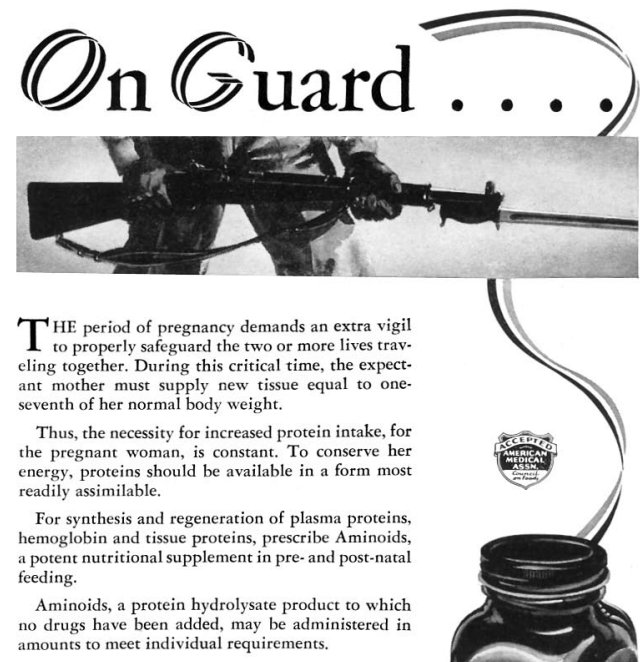
amounts to meet individual requirements.

\section{Aminoids

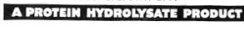 \\ For Oral Administration}

avaILABLE IN BOtTLES CONTAINING 6 OUNCES

The Arlington Chemical Company YONKERS Atrlington NEW YORK

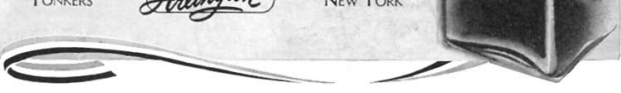

Figure 5

A 1943 advertisement in the $\mathrm{JCl}$ uses wartime imagery we are unlikely to associate today with the importance of adequate nutrition during pregnancy.
A

\author{
Now Available
}

\section{NEW antileukemic drug 'PURINETHOL'}

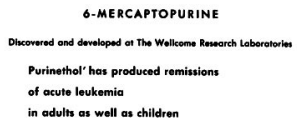

B

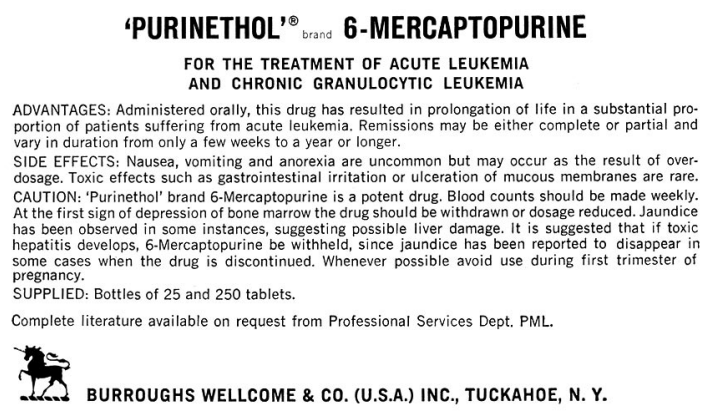

Figure 6

Advertisements for the antileukemic drug Purinethol in 1954 (A) and 1963 (B). The later ad reflects the Harris-Kefauver Amendment to the Food, Drug and Cosmetic Act in 1962, which established requirements for disclosure of drug mechanisms and side effects. 


\section{Pure.. \\ Wholesome.. Refreshing}

Safeguarded constantly by scientific tests, Coca-Cola is famous for its purity and wholesomeness. It's famous, too, for the thrill of its taste and for the happy after-sense of complete refreshment it always brings. Get a Coca-Cola, and get the feel of refreshment.

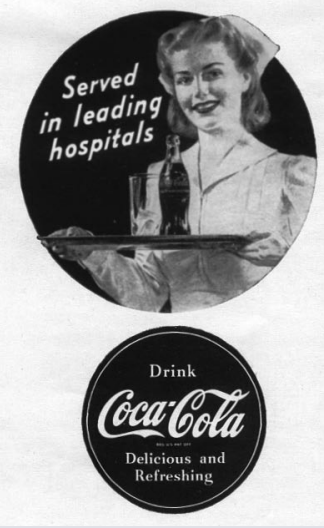

\section{Figure 7}

A $1946 \mathrm{JCl}$ advertisement for Coca-Cola. Given the link between sugar-sweetened drinks and incidence of diabetes in women (49), soda has long since disappeared from a physician-recommended diet.
In the 1950s the era of the "wonder drug" arrived as American and European research laboratories released a flood of new pharmaceuticals - antibiotics, steroids, antihistamines, oral hypoglycemics, and psychotropics - that revolutionized medicine and produced an advertising explosion. Previously untreatable diseases could suddenly be cured or alleviated, and inspiring messages of technological advances were delivered to health care practitioners. Companies drew upon Madison Avenue's creative talent as artistic graphics and challenging copy began to appear and saturation media strategies came into use. The basic promotional techniques of selling pharmaceuticals were established during this period, and ads from large companies such as Pfizer and Merck flooded the market.

The 1950s also saw a shift from physician-directed ads to those targeting the bench scientist, a reinforcement of the impact of evidence-based medicine and evolving technologies. Almost half the ads appearing in the JCI featured laboratory equipment, including centrifuges, incubators, and spectrophotometers. That is not to say that the complexity of marketing strategies evolved in parallel. Makers of laboratory chow reminded scientists that their "bright, attractive bags ... will add some color and atmosphere to your feed room."

The pharmaceutical industry collided with Senator Estes Kefauver of Tennessee during four years of Senate hearings to expose advertising fraud and industry stock manipulation. Spurred by demonstration of teratogenic effects of thalidomide in humans, the Harris-Kefauver Amendment to the Food, Drug and Cosmetic Act was introduced in 1962. The act mandated preclinical animal trials before the testing of drugs in humans and the demonstration of drug efficacy for a specific use before market release. Further legislation empowered the FDA to exercise greater oversight of prescription drug promotion, which was reflected in subsequent advertising. Compare and contrast two advertisements for the same antileukemic drug before and after this amendment (Figure 6, A and B, respectively). This degree of disclosure regarding mechanism of action, indications, administration, and adverse reactions remains mandatory.

In 1963, Coca-Cola was "served in leading hospitals," and while it was no longer purported to be a brain tonic, ads reminded us that "safeguarded constantly by scientific tests, Coca-Cola is famous for its purity and wholesomeness ... It contributes to good health by providing a pleasurable moment's pause from the pace of a busy day" (Figure 7). Forty years later, researchers would likely raise a flag, given the recent conclusion that higher consumption of sugar-sweetened beverages is associated with increased risk for development of type 2 diabetes in women (49).

As the old adage says, "sex sells," and the human element in advertisements primarily comprised women, as technicians or patients; men appeared rarely before the 1970 s except as traditionally senior figures, such as doctors. In 1969, a lead investigator could win "the gratitude of [his notably female] technologist for eliminating the tedium usually associated with manual methods of lipid analysis" (Figure 8). Racy reading!

Advertising peaked in 1970; ads for fellowships and for positions open for hospital staff and academics were included. The computer-industry revolution heralded the age of automation, reflected in the dominance of ads for an impressive array of automated high-throughput colony counters, pipettes, and analyzers. Advertisements focused mainly on experimental reagents, medical texts, and other journals under the Rockefeller University Press umbrella.

During the 1980s and until 1990, the JCI printed relatively few advertisements, most of which were restricted to scientific meetings, relevant texts, and employment opportunities. A combination of factors contributed to this transition: (a) Uncertainty regarding new federal health care legislation and the growth of managed care prompted a general decline in promotional expenditures. (b) In 1977 the FDA loosened restrictions on direct-to-consumer advertising of prescription drugs; companies no longer needed the stepping stone of the general practitioner to bring their product to the patient. (c) An increased number of specialty journals meant that advertisers could more efficiently reach their target audience elsewhere. (d) Potential conflicts of interest were perceived as arising from financial relationships between drug manufacturers and authors of studies submitted and/or published in the JCI.

\section{Brooke Grindlinger, Science Editor}

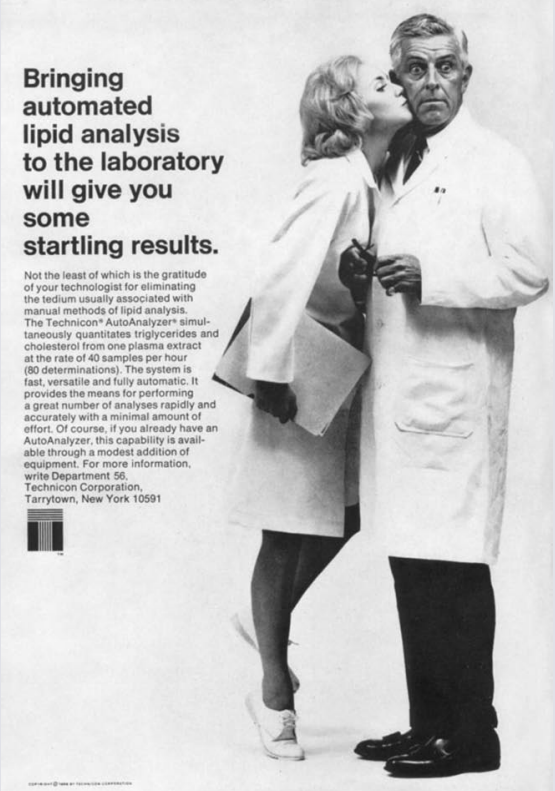

Figure 8

The old adage holds true: sex sells (1969). 


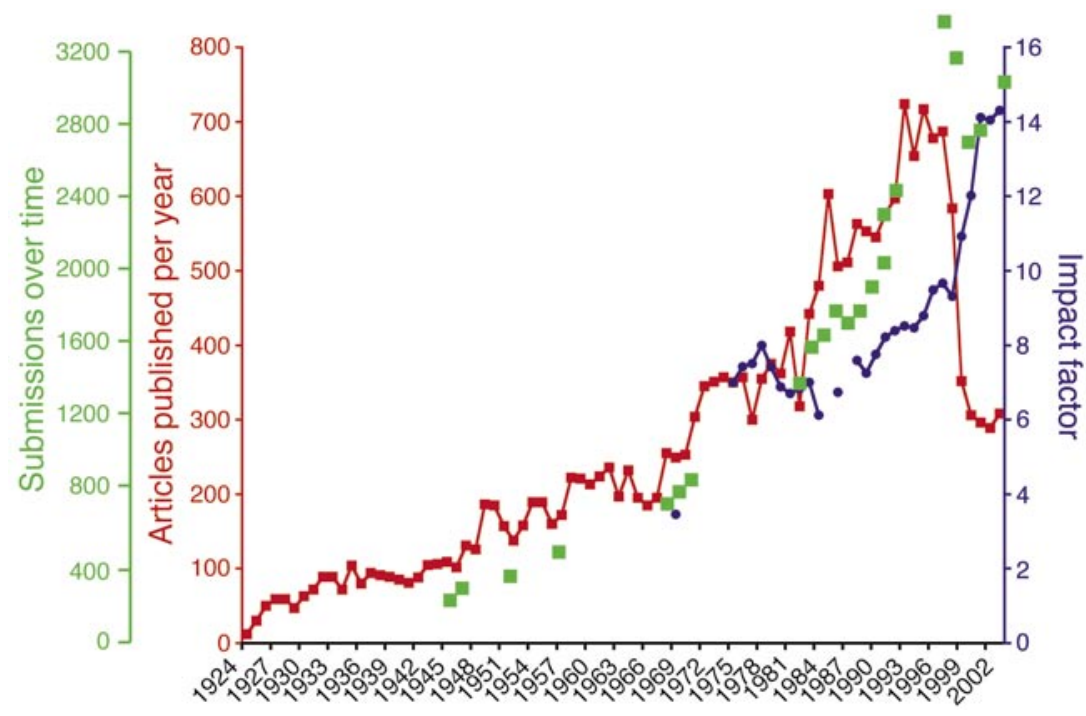

Figure 3

Data on the number of articles published in the $\mathrm{JCl}$ from 1924 to 2003 (red) alongside the total number of articles submitted for consideration (green). The JCl's impact factor (blue), calculated by the Thomson Institute for Scientific Information, represents the current number of citations of articles the $\mathrm{JCl}$ has published in the previous 2 years; this index is used as an objective measure of the influence of journals in their chosen discipline. Broken lines indicate that data from these time periods are unavailable.

The proceedings and abstracts of the annual ASCI meeting, held in concert with the annual meetings of the Association of American Physicians and the American Federation for Clinical Research, had always been published in the JCI, but in 1975, the decision was made to move the abstracts to the journal Clinical Research. The presidential and award lectures, however, continue to be printed in the JCI and provide a rich history of the challenges faced by physician-scientists over the years.

In the editorial commemorating the Journal's 50th anniversary in 1974, editor-inchief Jean D. Wilson lamented the increasing number of specialty journals introduced in the 1960s and 1970s, as he felt this decreased the number of submissions the JCI received (5). However, submissions continued to increase during this time (Figure 3). Wilson instituted another important change, most likely due to the state of the Journal's finances: the submission fee (Figure 2).

Older, wiser, better? The JCI from the 1980s onward. Volume 75 in 1985 saw page design change again in an otherwise calm period for the JCI. The most major innovation of the 1980s occurred when editor-in-chief Thomas Stossel began running review articles (Perspectives) in 1983. The first, by Joseph Goldstein and Michael Brown, focused on lipoprotein receptors in the liver (6). The editors subsequently succeeded in publishing a
Perspective in nearly every issue. The increase in page charges from 1983 onward likely occurred in part to offset the ever-increasing volume of reviews, as no page charges were levied for such invited material.

In the 1990s, Bruce F. Scharschmidt, editor-in-chief, introduced a new cover (in color!) for the Journal and segregated the articles by topic into sections in the table of contents. Scharschmidt increased the number of associate editors he worked with to evaluate the manuscripts when they were first submitted. He also introduced consulting editors (the JCI's most frequent referees and consultants outside of the editorial board) as a replacement for the editorial committee. Ajit Varki took over the editorship of the JCI in 1992 and modernized the operation by establishing computerized tracking of manuscripts. He published a letter on the "Editorial policies and practices of the JCI," wherein he discussed the nature of manuscripts well suited to the Journal, the rules of submission and review, and the expected time frames for publication. In 1993, Varki began soliciting "Editorials" (now called Commentaries) that helped put research articles in context for a larger audience.

Many alterations to the JCI occurred in 1996: it adjusted to a twice-monthly publication schedule, and articles were published online at www.jci.org through the services of HighWire Press. At this juncture, the editorial board and ASCI decided to offer all content online without a barrier of any sort to all users (7). In order to maintain solid financial footing, the Journal increased publication fees to authors to offset declining subscription revenue (Figure 2). Much has been written and said about the openaccess/free-access movement $(4,8,9)$; it is remarkable that the JCI had such foresight before the current controversies were even conceived. The decision to remain a freeaccess journal is one that the editors since Varki have upheld and continue to support.

Another, different cover layout was established in 1999, and complex figures started appearing in the Commentaries. Editor-in-chief Stephen J. Weiss introduced a number of other features - In this Issue; thematic series of Perspectives that spanned several issues; and letters to the editor. In 1997, Weiss hired the JCI's first professional full-time science editor to handle the increase in review materials and started sending press releases to the lay press. As noted earlier, Weiss and the editors decided in 1999 to cease the relationship with Rockefeller University Press and to begin self-publishing.

The current editor-in-chief, Andrew Marks (the son of the previous editorin-chief Paul Marks), assumed the reins in 2002 and has since launched two new series, Science in Medicine and Science and Society (10). Soon afterward, news articles and book reviews were also added to make the Journal more appealing to a broad audience. It is perhaps too early to remark on whether these additions will have a palpable impact on our readership.

Each changing of the guard has infused new ideas that have heralded improvements in both the operation and the aesthetic of the JCI. Most importantly, though, the quality of the scientific discoveries recorded in our pages has continued to be our most significant asset.

\section{The science behind the $\mathrm{JCI}$}

What sort of articles does the JCI publish? The answer has changed over time, but there is a core of topics on which the JCI has always remained focused: blood, kidney physiology, heart failure, and metabolism. Philip Bondy noted in 1959 that the Journal of Clinical Investigation was not so clinical anymore (2). This sentiment was echoed throughout the years and certainly seems true today. The JCI is shaped largely by what it receives, and over the years it has received 
more mechanistic papers and fewer clinical ones; this may reflect the maturation of research tools and the recent development of sophisticated animal models and genetic technology that allow us to better dissect human diseases at the molecular level. Nevertheless, the Journal's roots are in clinical medicine, and our goal has always been to reach this arena.

When the JCI was launched, the articles were, almost without exception, studies on human subjects. Nearly $30 \%$ were published by single authors without collaborators. A large proportion were multipart companion studies, like the five-part "Studies of urea excretion" (11-14). Most of the articles published stayed close to the core topics mentioned above.

The 1930s brought an increasing number of studies on animals (chickens, dogs, horses, and rats), though nearly $98 \%$ of the articles reported human data. More international authors - mostly European - sought and gained publication in the JCI. There seems to have been an inordinate number of articles (17 during the 1930s) on measuring radiation of heat from the human body. While the papers were still largely connected to the JCI's core topics, there were also many on liver physiology, pregnancy, and gas exchange. It is interesting to note that many articles dealt with diseases for which scientists have developed treatments, or for which more precise definitions now exist: pellagra, rheumatic fever, gout, Bright disease, goiter, and pernicious anemia, among others. The late 1930s brought more infectious-disease research to the pages of the $J C I$, with a number of studies on gonococcal infections and encephalitis viruses.

Research reported in the Journal up to this point had been essentially descriptive, and papers in the 1940s were no different, including one article, "Some properties of human fetal and maternal blood" (15), that today would likely be rejected based on the title alone. These papers largely described humans and formed the foundation of our current understanding, so they certainly had a place in the literature. There was also a growing number of papers related to cancer and infectious disease. Manuscripts on more exotic maladies (typhoid, gonorrhea, Fort Bragg fever [ref. 16], and malaria) were popular as well, probably because of the world's focus on World War II. War priorities were evident as the JCI ran several articles on treatment of traumatic shock, gangrene, transfusions, bacterial resistance to peni- cillin, amputations, and the best methods for storing blood.

Multipart studies were still popular throughout the 1940s, and single-author studies were still the norm, but the 1950s brought fewer of both. Significantly more animal studies appeared in the 1950s, but this may reflect a change in what the editors determined to constitute a good JCI paper: research was maturing in its approach, and papers were designed to address mechanism, a more difficult feat when performed in human subjects. Studies began to focus more on hormone excretion, transport, and other issues in the organ systems - certainly less "sexy" topics than those popular in the war-driven 1940s.

Multipart, single-author, and human studies became uncommon in the 1960s, as mechanisms were more aggressively pursued in vitro. Many of the human studies embraced genetics and looked at polymorphisms; genetic studies had rarely been published in the JCI prior to this time. Words like "pathogenesis" and "mechanism" replaced "kinetics" and "further studies on ..." in the titles of the articles published in the 1960s. Methodology papers, particularly those on radioimmunoassays (RIAs), were still popular with the editors as well. Also popular with the editors was the topic of urinary and metabolic output of pregnant women - 29 papers were published on the topic.

The 1970s brought an increase in the number of articles published; the research was sophisticated and no longer very descriptive. The only remaining methods papers dealt with RIAs, but some of these were important, describing assays for triiodothyronine, apolipoproteins A and $\mathrm{B}$, parathyroid hormone, myoglobin, somatomedin, vitamin D-binding protein, and mucin, among others. The Concise Publications, begun in 1971, added progeria, neuropathy, various infectious diseases, cancer, steroids, skin, circadian rhythms, puberty, and lupus to the core subjects addressed by the Journal's regular articles.

More in vitro data were published in the 1980s, but the balance of the papers were split about evenly between human and animal studies. Fewer methods papers than ever appeared, and gone were the multipart studies that had been so popular in the early days of the JCI. In the early 1980s, the Journal's core topics predominated again, but the latter part of the decade saw an explosion of diversity in subject matter - gastrointestinal disor- ders, hormonal defects, cancer, immunology, autoimmunity, and virology.

Varki declared the scope of the Journal too narrow in 1992 (17), but by my reading, the focus was as wide as in years past, including papers on cancer, genetics, infectious diseases, and immunology. But Varki decried the then-current state of affairs and claimed too many of the papers were based on in vitro and animal studies and too few on studies in humans. He was right that the balance had tipped much more in favor of animal and in vitro data.

Irrespective of subject matter then and now, many seminal contributions have been made in the JCI and have had a significant impact on clinical medicine.

\section{Landmark studies published in the $\mathbf{J C I}$}

Over the course of 80 years and 114 volumes, the JCI has published some of the most important biomedical studies. We are fortunate that many former editors-inchief are alive and can reflect on the science that crossed their desks during their tenure. Beginning on page 1017, the former editors have contributed summaries of several studies that they found particularly memorable. In addition, beginning on page 1034, we have commissioned eight retrospectives on our most cited articles from the archive (18-28). These retrospectives were conceived to provide a basic understanding of the original articles while reflecting on the context of the times in which they were written. The works were revolutionary at the time of publication and built the foundation of a rich legacy of scientific discovery for others.

There are many other noteworthy papers that do not appear later in the issue, so I want to take this opportunity to mention them; the sidebar (Landmark findings, important discoveries, and interesting studies) describes some. The selection of these papers may seem arbitrary; they simply piqued my curiosity as I read through many issues from the archive. For a different perspective on early works published in the JCI, I suggest the excellent summary by former editorin-chief Philip Bondy on the occasion of the Journal's 35 th anniversary (2). A list of the ten most cited articles of each decade since 1945 is also available (Supplemental data; available at http://www.jci.org/cgi/ content/full/114/8/1006/DC1).

Patient descriptions. The ethics of the privacy of subjects and of what is deemed acceptable 
Landmark findings, important discoveries, and interesting studies

1927 John S. Lawrence described the first white patient with sickle cell anemia; it had previously been thought that this disease only affected black people (50).

1929 The iron lung was first described in the $J C /$ for use on adults and children in need of artificial respiration (51). Electrically operated pumps were used to create negative and positive pressure in the tank; positive pressure induced expiration and negative pressure induced inhalation (Figure 9).

1930 Paul Reznikoff was the first to use nucleotide therapy in humans for treating agranulocytosis. The therapy had previously been shown to work in rabbits; this was an early version of translational research (52).

1931 The $\mathrm{JC}$ / published the first investigation of the QT interval (on an EKG) for measuring systole and myocardial aberrations (53). Long QT syndrome is now acknowledged as an arrhythmic state.

1936 A clever group from Yale discovered a way to measure the volume of extracellular fluids in the body (54).

1936 The now omnipresent low-carbohydrate diet was initially proposed by Cyril MacBryde as a dietary treatment for diabetics (55).

1937 Plasma volume was determined with inferior methods until the introduction of Evans blue dye in this article (56).

1939 Bauer and colleagues determined that the aqueous solution in joint spaces derived almost entirely from the vasculature as opposed to being secreted by chondrocytes (57). Later that same year, Bauer's group more fully characterized the aqueous synovial fluid (58).

1945 C.E. Koop (later the surgeon general of the US) and colleagues tested gelatin as a plasma substitute and showed that it could be an effective agent in restoring and maintaining blood volume following acute hemorrhage (59).

1950 The latest innovation in the development of an artificial kidney was presented in a doublet $(60,61)$. This model employed a rotating drum (Figure 10) and proved more effective than previous models at removing toxic substances from the blood without any hazard to the patient.

1962 The discovery of the mechanism of action of thrombin on platelets (through fibrinogen) was published in the $\mathrm{JCl}(62)$.

1963 Researchers in Philadelphia were able to determine the levels of production of endogenous CO, and its source, by making subjects rebreathe through a specially designed apparatus (63).

1964 Authors showed that rabbits had to have an elevated body temperature in order for endotoxin challenge to cause any detrimental effects (64). This finding carried profound clinical implications for the management of patients with bacterial infections.

1964 John Merrill and colleagues (of rotating-drum artificial-kidney fame) showed that, in patients without kidneys, erythropoiesis could continue (65). It had previously been thought that all erythropoietin was derived from the kidney.

1966 Rockefeller researchers showed that DNA and anti-DNA antibodies in the serum of lupus patients are pathogenic (66).

1967 Three obese patients were starved for 38-41 days in order to show that the brain switches from using glucose as fuel to using $\beta$-hydroxybutyrate and acetoacetate (67).

1969 The major role of ATP in erythrocytes was described. Most of the ATP in an RBC is expended in preserving membrane deformability (68).

1970 Jean Wilson (former editor-in-chief) and Pentti Siiteri showed that testosterone plays a central role in the hypertrophy of the prostate and that imbalance of its levels could lead to prostate cancer (69).

A

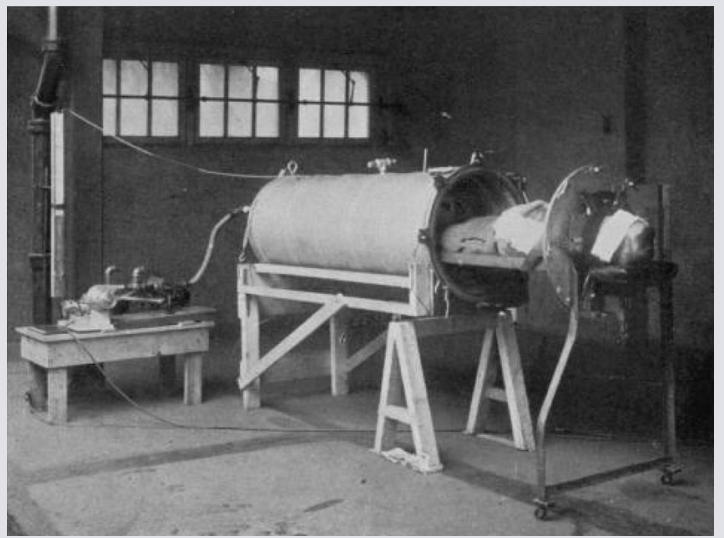

B

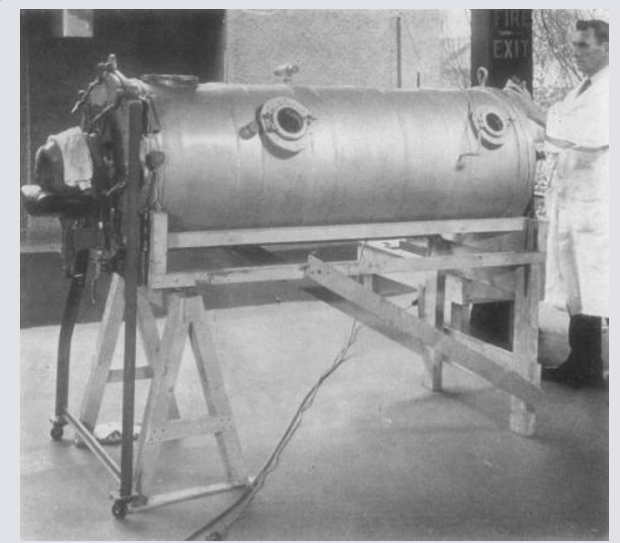

\section{Figure 9}

The iron lung. The following legends accompanied the original figures: (A) Mechanical respirator, showing tank with pump mechanism connected by flexible tube at foot end. The collar and head rest are in place and the patient is ready to be pushed into the tank. (B) A patient in the respirator. Note the position of the portholes. Attendant has his hands on the dial of the thermostat which controls the temperature and humidity of the air in the tank. Reprinted from ref. 51. 
1973

1973

1975

1977

1980

1981

1983

1984

1987

1988

1989

1992

1993

1994

1997

1999

2001

2002

Arno Motulsky and colleagues published a triplet of groundbreaking papers on the link between hyperlipidemia and myocardial infarction (70-72).

Six growth hormone-deficient children who had been given exogenous human growth hormone (HGH) were described (73). While the children responded to HGH vigorously in the short course, they lost responsiveness over time, and HGH therapy was thenceforth not recommended as the only therapy for growth-retarded children.

Philip Majerus (another former editor-in-chief) and G.J. Roth detailed the mechanism of action of aspirin on platelets (74).

Genital secretions were found to be antibacterial (at least in the case of gonorrhea) (75).

Robert Hebbel and colleagues showed that abnormal $\mathrm{Ca}^{++}$signaling causes sickle RBCs to adhere to the vascular endothelium, resulting in vessel occlusion (76).

Another advance in understanding sickle cell anemia was reported when Ronald Nagel and colleagues found that mutations in the $\beta$-globin gene originally arose in two separate but geographically close regions in western Africa (77).

Richard Boucher and colleagues showed that there was a permeability defect in the respiratory epithelium of cystic fibrosis patients (78). This group was the first to recognize that an ion defect (namely, a defect in $\mathrm{Na}^{+}$ion transport) caused the difference in transepithelial resistance between epithelia of cystic fibrosis patients and normal epithelia.

While it seems elementary now that oxygen radicals are involved in ischemia/reperfusion injury in the kidney, it was first reported in 1984 (79).

Platelets (or substances secreted by platelets) were shown to be a driving force in macrophage foam cell generation (80).

Roberto Bolli and colleagues used an ingenious spin-trap technique to show that oxidant radicals were also important for myocardial ischemia (81).

The $\mathrm{JC} /$ published the first report that cells of a myeloid lineage (neutrophils) could indeed apoptose (82). The apoptotic neutrophils could then be recognized and taken up by macrophages, leading to the resolution of inflammation.

A French group showed that i.v. injection of an adenovirus could result in widespread, long-term expression of a reporter gene ( $\beta$-galactosidase in this case) in skeletal and cardiac muscle (83). This paper laid the groundwork for many studies attempting to use gene therapy for diseases from myocardial infarction to muscular dystrophy.

A revolution in the atherosclerosis field was begun with the publication of the LDL receptor knockout mouse (84), hot on the heels of the publication of the description of the apoE knockout in Science the year before (85). These models, still the most popular used today by atherosclerosis researchers, have allowed significant insights into the processes and interactions involved in atherogenesis.

Apoptosis was still at the forefront of science when it was shown for the first time that cardiac ischemia led to myocyte apoptosis (86).

Leptin had been discovered and described, but William Haynes and colleagues were the first to show that it was responsible for increases in sympathetic outflow to brown adipose tissue (87). These effects suggested a novel role for leptin in neural control of the circulation.

Cardiomyocytes had been thought for years to be static, nonreplicating cells. With the promise of stem cells differentiating into every tissue of the body, the race was on to be the first to produce cardiomyocytes from stem cells or bone marrow progenitors. A Japanese group won the race, and their findings were published in the $\mathrm{JCl}$ in 1999 (88).

Further toward the goal of regenerating myocardium, Margaret Goodell and colleagues transplanted HSCs into infarcted myocardium and showed that donor cells engrafted and became both myocytes and endothelial cells (89).

Patients with lipodystrophy were successfully treated with leptin to reverse their insulin resistance and hepatic steatosis (90).

It is perhaps cheeky to choose an article from the past year, but a doublet published in late 2003 is particularly noteworthy $(91,92)$. In these articles, the authors showed that adipose tissue is characterized by macrophage infiltration and that these macrophages are an important source of inflammation.

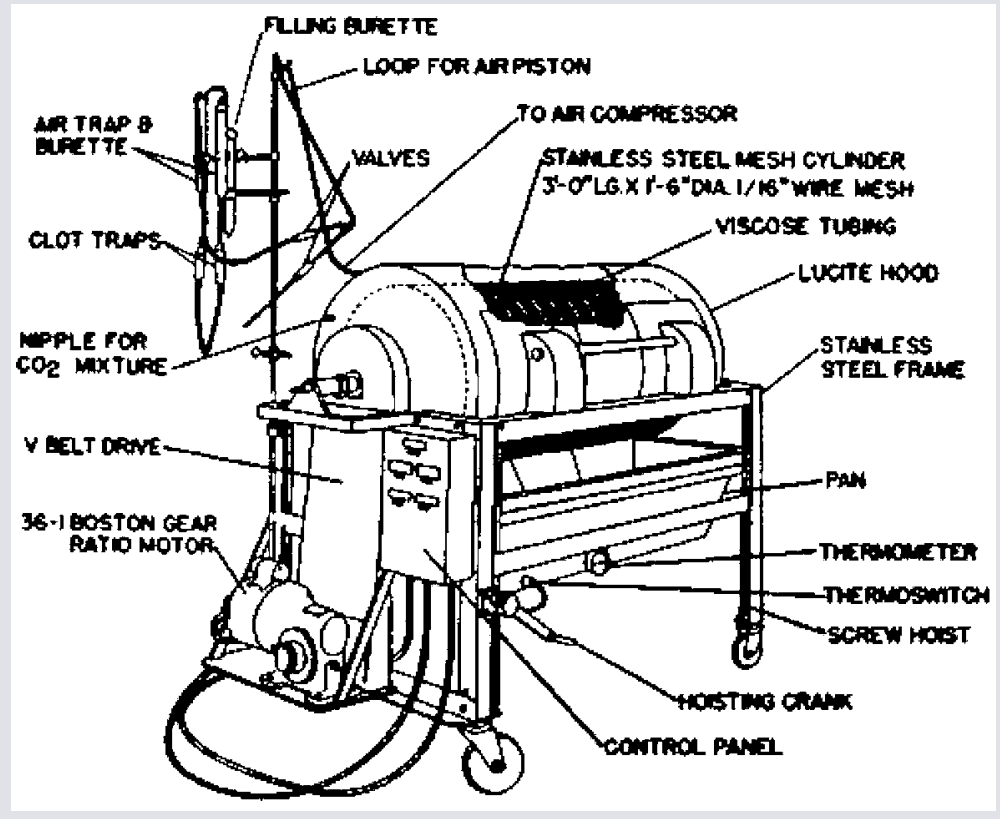

Figure 10

Isometric view of the rotating-drum artificial kidney. Reprinted from ref. 60 . 


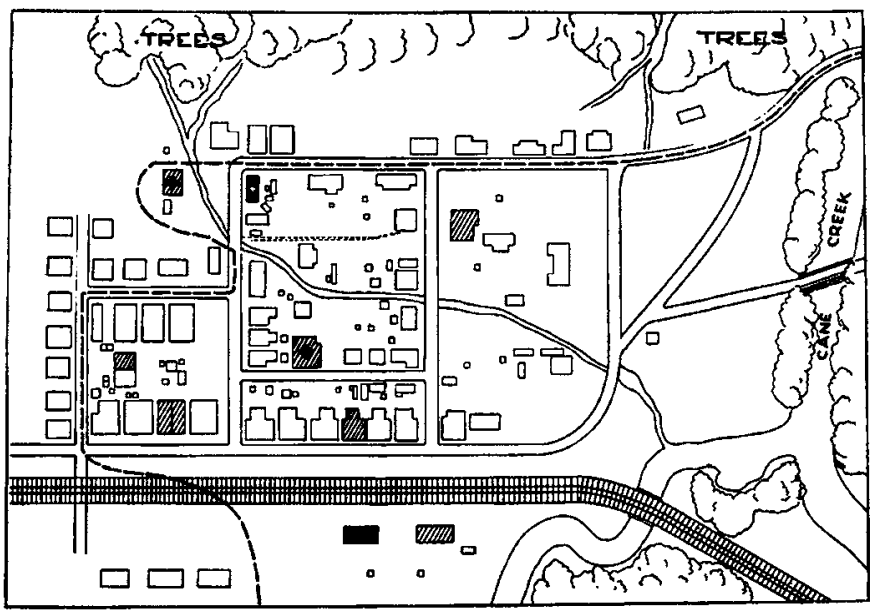

\section{Figure 4}

Diagram of community studied. The community is outlined by the broken line and the lower and right-hand margins of the figure; the area is roughly $1000 \times 600 \mathrm{ft}$. The black blocks represent houses in which paralytic poliomyelitis occurred; the shaded blocks represent houses in which abortive poliomyelitis occurred. The residence of individuals with positive stools is indicated by a cross. Figure and legend reprinted from ref. 35.

experimentation have changed considerably over the years. Some entertaining (and questionable) examples include the following:

In 1926, "A Jewish housewife, age 68 ... who was complaining bitterly" was enrolled in a study on polycythemia (29). A full history with first name, last initial, and age was given for each hemorrhagic patient studied in 1928 (30). Authors got right to the point in 1928, as Gulli Muller stated, "fat people as a rule tend to have less hemoglobin than thin people" (31). Occupations also made their way into the medical history in the early 1930s, and one article additionally disclosed the patients' medical record numbers and listed the hospital where treatment was given (32). No specific details were given in a study from 1939 on 40 men committed to jail for repeated drunkenness (33), though it is unlikely the subjects would have been able to give full medical histories anyway. Drunkenness seems to have been at the forefront of science in 1939 , as researchers at Bellevue Hospital studied "alcoholic patients who had a history of drinking and a definite odor of alcohol on the breath" (34).

A study tracking poliomyelitis outbreaks in a small town in Alabama in 1943 went the furthest in revealing identities: the authors published a map of the town they tracked (Figure 4) and listed the children's names throughout the article (35). Manley, Doyle, Elma, Lamarr, Hershel, and Hardy were all studied (the difference in names popular at the time is also remarkable). Later in the same issue, a subject is described as a " 57 year old, white, unmarried, female musician" (36) - a description that would not likely make it into the pages of the JCI today.

Though in 1953 a 42-year-old widow was described as complaining of malaise as "she had been accustomed for a long time to taking indeterminate but large amounts of proprietary laxative compounds" (37), by the 1950s, the descriptions of patients were usually limited to initials, age, and employment. The decrease in detail continued through the 1960s and 1970s, as patients were simply described as "young, healthy volunteers" or "19 random patients on the hospital ward." Today, very little information about human subjects is given other than averages of an agematched, sex-matched group.

Studies unlikely to be published today. The JCI has always adhered to the principles of the Declaration of Helsinki, even before they were adopted in 1964 . We require our authors to seek ethical approval for their studies prior to submission. Despite this, several questionable studies made their way into the pages of the JCI in the early days, but would not likely be published today.

In 1941, the authors of a study on pain used vibration, sharp wooden edges, a homemade electric stimulator, and a static electricity generator on themselves (38). Prolonged water and food starvation (11-20 days) of dogs was performed in 1942 to investigate the volume of body fluids and renal function (39). It is unlikely an institutional review board would allow such inhumane treatment of animals today.

While there was nothing ethically wrong with a triplet of papers published in 1946 and 1948 , it is rather unlikely that the JCI today would find a disease application for studies on men sitting quietly in the cold (40), or on the influence of clothing on physical activity in conditions of intense heat $(41,42)$. Another study that would not likely be approved today was printed in 1948, when 90 orphans in Farmington, Michigan, were injected with influenza after being given various diluted amounts of a vaccine (43). It seems anything was possible in 1948: 500 prisoners at Illinois State Penitentiary whose stay was to be longer than 18 months were stung ten times by malaria-infected Anopheles quadrimaculatus mosquitoes. Many of the prisoners, serving as controls, received no prophylactic or postinfection drugs whatsoever (44).

A decade later, the science had matured, but apparently the approach had not. In 1959, 1,034 University of Illinois students in medicine, nursing, dentistry, or pharmacy were given nasal secretions from different ill donors whose "nonfebrile, coryzal illness had the characteristics of a common cold" (45). Some of the students even received nonspecific secretions that were over 6 years old.

In 1964, the JCI published two other gems worth mentioning. In one study, newborn babies were either kept warm or left uncovered in a $22.5^{\circ} \mathrm{C}$ room to study prolongation of respiratory and metabolic acidosis (46). Few parents would likely enroll their infant in such a study today. In the other study, 15 healthy, adult males were hooked up to pressure transducers while defecating - either naturally or while intensely squeezing (47). Apparently the study was meant to determine the sphincter pressure needed for expulsion.

In the final impractical study highlighted here researchers in Vermont in 1971 convinced prison wardens to allow them to study five healthy male prisoners on a highcalorie diet for 3-4 months (48). The prisoners gained $15-25 \%$ of their body weight (16.2 $\mathrm{kg}$ on average; $10.4 \mathrm{~kg}$ of the gain was fat). Such a study may indeed be feasible today, but it is unlikely any researcher would condone it.

\section{Conclusions}

It is with an enormous amount of respect for the previous editors that I conclude this history of the JCI. The challenges we face today 
may be somewhat different from those they earlier met and conquered, but we have them to thank for leaving us with such a treasured journal. Their high standards have given the JCI an important position in the field of biomedical science. We also owe a debt of gratitude to the many authors and reviewers who have labored on our behalf.

The JCI has been one of the most important vehicles for expression of the ASCI's ideals and has constantly kept alive the principle of excellence that prompted the founding editors to establish the Journal. As the JCI enters its ninth decade, we hope to maintain the high standards set by those who came before us.

\section{Acknowledgments}

I would like to thank Sara Sprague, JCI Editorial Assistant, for her help in assembling subscription and publication data, and Brooke Grindlinger, JCI Science Editor, for helping to edit the manuscript.

\section{Ushma Savla, Executive Editor}

1. Cohn, A.E. 1924. Purposes in medical research: an introduction to the Journal of Clinical Investigation. J. Clin. Invest. 1:1-11.

2. Bondy, P.K. 1959. History of the Journal of Clinical Investigation, 1924-1959. II. Scientific contents. J. Clin. Invest. 38:1873-1878

3. Brainard, E.R. 1959. History of the Journal of Clinical Investigation, 1924-1959. I. Personnel and policies. J. Clin. Invest. 38:1865-1872.

4. Hawley, J. 2004. Is free affordable? Access to the literature: the debate continues. Nature web focus. http://www.nature.com/nature/focus/accessdebate/14.html.

5. Wilson, J.D. 1974. The Journal of Clinical Investigation 1974. J. Clin. Invest. 56:xv-xvii.

6. Brown, M.S., and Goldstein, J.L. 1983. Lipoprotein receptors in the liver: control signals for plasma cholesterol traffic. J. Clin. Invest. 72:743-747.

7. Varki, A.P. 1996 . The times they are still a'changing: keeping up with the times. J. Clin. Invest. 97:1.

8. Hawley, J. 2003. The JCI's commitment to excellence - and free access. J. Clin. Invest. 112:968-969. doi:10.1172/JCI200320030.

9. Savla, U., and Hawley, J. 2004. Want the world to know? Publish here. J. Clin. Invest. 114:602.

10. Marks, A.R. 2003. The JCI starts two new series: Science in Medicine and Science and Society. J. Clin. Invest. 111:289.

11. Mackay, E.M. 1928. Studies of urea excretion. V. The diurnal variation of urea excretion in normal individuals and patients with Bright's disease. J. Clin. Invest. 6:505-516.

12. Mcintosh, J.F., Möller, E., and Van Slyke, D.D. 1928. Studies of urea excretion. III. The influence of body size on urea output. J. Clin. Invest. 6:467-483.

13. Möller, E., Mcintosh, J.F., and Slyke, D.D.V. 1928. Studies of urea excretion. II. Relationship between urine volume and the rate of urea excretion by normal adults. J. Clin. Invest. 6:427-465.

14. Möller, E., Mcintosh, J.F., and Slyke, D.D.V. 1928. Studies of urea excretion. IV. Relationship between urine volume and rate of urea excretion by patients with Bright's disease. J. Clin. Invest. 6:485-504.

15. Darling, R.C., Smith, C.A., Asmussen, E., and Cohen, F.M. 1941. Some properties of human fetal and maternal blood. J. Clin. Invest. 20:739-747.

16. Tatlock, H. 1947. Studies on a virus from a patient with Fort Bragg fever (pretibial fever). J. Clin. Invest. 26:287-297.

17. Varki, A. 1992. The times they are a'changin': changing with the times. J. Clin. Invest. 89:721-722.

18. Havel, R.J., Eder, H.A., and Bragdon, J.H. 1955. The distribution and chemical composition of ultracentrifugally separated lipoproteins in human serum. J. Clin. Invest. 34:1345-1353.

19. Jaffe, E.A., Hoyer, L.W., and Nachman, R.L. 1973. Synthesis of antihemophilic factor antigen by cultured human endothelial cells. J. Clin. Invest. 52:2757-2764.

20. Jaffe, E.A., Nachman, R.L., Becker, C.G., and Minick, C.R. 1973. Culture of human endothelial cells derived from umbilical veins. Identification by morphologic and immunologic criteria. J. Clin. Invest. 52:2745-2756.

21. Dole, V.P. 1956. A relation between non-esterified fatty acids in plasma and the metabolism of glucose. J. Clin. Invest. 35:150-154.

22. Dubois, A.B., Botelho, S.Y., Bedell, G.N., Marshall, R., and Comroe, J.H., Jr. 1956. A rapid plethysmographic method for measuring thoracic gas volume: a comparison with a nitrogen washout method for measuring functional residual capacity in normal subjects. J. Clin. Invest. 35:322-326.

23. Dubois, A.B., Botelho, S.Y., and Comroe, J.H., Jr. 1956. A new method for measuring airway resistance in man using a body plethysmograph: values in normal subjects and in patients with respiratory disease. J. Clin. Invest. 35:327-335.

24. Kety, S.S., and Schmidt, C.F. 1948. The nitrous oxide method for quanititative determination of cerebral blood flow in man: theory, procedure and normal values. J. Clin. Invest. 27:476-483.

25. Kety, S.S., and Schmidt, C.F. 1948. The effects of altered arterial tensions of carbon dioxide and oxygen on cerebral blood flow and cerebral oxygen consumption of normal young men. J. Clin. Invest. 27:484-492.

26. Smith, H., Finkelstein, N., Aliminosa, L., Crawford, B., and Graber, M. 1945. The renal clearances of substituted hippuric acid derivatives and other aromatic acids in dogs and man. J. Clin. Invest. 24:388-404.

27. Yalow, R.S., and Berson, S.A. 1960. Immunoassay of endogenous plasma insulin in man. J. Clin. Invest. 39:1157-1175.

28. Babior, B.M., Kipnes, R.S., and Curnutte, J.T. 1973. Biological defense mechanisms. The production by leukocytes of superoxide, a potential bactericidal agent. J. Clin. Invest. 52:741-744.

29. Long, P.H. 1926. Effect of phenylhydrazine derivatives in the treatment of polycythemia. J. Clin. Invest. 2:315-328

30. Hartmann, A.F., Darrow, D.C., and Morton, M. 1928. Chemical changes occurring in the body as a result of certain diseases in infants and children. II. Acute hemorrhagic nephritis. Sub-acute nephritis; severe chronic nephritis. J. Clin. Invest. 6:127-157.

31. Muller, G.L. 1928. The influence of a diet, high in butter fat, on growth, blood formation and blood destruction. J. Clin. Invest. 5:521-529.

32. Cohn, A.E., and Steele, J.M. 1934. Unexplained fever in heart failure. J. Clin. Invest. 13:853-868.

33. Seymour, W., Spies, T.D., and Payne, W. 1939. The gastric secretion in chronic alcoholic addiction. J. Clin. Invest. 18:15-18.

34. Goldfarb, W., Bowman, K.M., and Parker, S. 1939. The treatment of acute alcoholism with glucose and insulin. J. Clin. Invest. 18:581-584.

35. Wenner, H.A., and Alber, E.C. 1943. A community study of carriers in epidemic poliomyelitis. J. Clin. Invest. 22:117-125.

36. Shapiro, S., Victor, R., and Moore, D.H. 1943. A viscous protein obtained in large amount from the serum of a patient with multiple myeloma. J. Clin. Invest. 22:137-142.

37. Schwartz, W.B., and Relman, A.S. 1953. Metabolic and renal studies in chronic potassium depletion resulting from overuse of laxatives. J. Clin. Invest. 32:258-271.

38. Gammon, G.D., and Starr, I. 1941. Studies on the relief of pain by counterirritation. J. Clin. Invest. 20:13-20.

39. Elkinton, J.R., and Taffel, M. 1942. Prolonged water deprivation in the dog. J. Clin. Invest. 21:787-794.

40. Horvath, S.A., Golden, H., and Wager, J. 1946. Some observations on men sitting quietly in extreme cold. J. Clin. Invest. 25:709-716.

41. Nelson, N.A., Shelley, W.B., Horvath, S.M., Eichna, L.W., and Hatch, T.F. 1948. The influence of clothing, work, and air movement on the thermal exchanges of acclimatized men in various hot environments. J. Clin. Invest. 27:209-216.

42. Shelley, W.B., Eichna, L.W., and Horvath, S.M. 1946. The effect of clothing on the ability of men to work in intense heat. J. Clin. Invest. 25:437-446.

43. Quilligan, J.J., Jr., Minuse, E., and Francis, T. 1948. Homologous and heterologous antibody response of infants and children to multiple injections of a single strain of influenza virus. J. Clin. Invest. 27:572-579.

44. Alving, A.S., et al. 1948. Procedures used at Stateville penitentiary for the testing of potential antimalarial agents. J. Clin. Invest. 27:2-5.

45. Jackson, G.G., and Dowling, H.F. 1959. Transmission of the common cold to volunteers under controlled conditions. IV. Specific immunity to the common cold. J. Clin. Invest. 38:762-769.

46. Gandy, G.M., Adamsons, K., Jr., Cunningham, N., Silverman, W.A., and James, L.S. 1964. Thermal environment and acid-base homeostasis in human infants during the first few hours of life. J. Clin. Invest. 43:751-758.

47. Harris, L.D., and Pope, C.E., 2nd. 1964. "Squeeze" vs. resistance: an evaluation of the mechanism of sphincter competence. J. Clin. Invest. 43:2272-2278.

48. Salans, L.B., Horton, E.S., and Sims, E.A. 1971. Experimental obesity in man: cellular character of the adipose tissue. J. Clin. Invest. 50:1005-1011.

49. Schulze, M.B., et al. 2004. Sugar-sweetened beverages, weight gain, and incidence of type 2 diabetes in young and middle-aged women. JAMA. 292:927-934.

50. Lawrence, J.S. 1927. Elliptical and sickle-shaped erythrocytes in the circulating blood of white persons. J. Clin. Invest. 5:31-49.

51. Drinker, P., and Shaw, L.A. 1929. An apparatus for the prolonged administration of artificial respiration. I. A design for adults and children. J. Clin. Invest. 7:229-247.

52. Reznikoff, P. 1930. Nucleotide therapy in agranulocytosis. J. Clin. Invest. 9:381-391.

53. Cheer, S., and Dieuaide, F. 1931. Studies on the electrical systole (" $Q-T$ " interval) of the heart. II. Its duration in cardiac failure. J. Clin. Invest. 10:889-913.

54. Lavietes, P.H., Bourdillon, J., and Klinghoffer, K.A. 1936. The volume of the extracellular fluids of the body. J. Clin. Invest. 15:261-268.

55. Macbryde, C.M. 1936. Response to insulin as an index to the dietary management of diabetes. J. Clin. Invest. 15:577-589.

56. Gibson, J.G., 2nd, and Evans, W.A., Jr. 1937. Clinical studies of the blood Volume. I. Clinical application of a method employing the azo dye "Evans Blue" and the spectrophotometer. J. Clin. Invest. 16:301-316.

57. Rhinelander, F.W., Bennett, G.A., and Bauer, W. 1939. Exchange of substances in aqueous solution between joints and the vascular system. J. Clin. Invest. 18:1-13.

58. Ropes, M.W., Bennett, G.A., and Bauer, W. 1939. 
The origin and nature of normal synovial fluid. J. Clin. Invest. 18:351-372.

59. Fletcher, A.G., Jr., Hardy, J.D., Riegel, C., and Koop, C.E. 1945. Gelatin as a plasma substitute: the effects of intravenous infusion of gelatin on cardiac output and other aspects of the circulation of normal persons, of chronically ill patients, and of normal volunteers subjected to large hemorrhage. J. Clin. Invest. 24:405-415.

60. Merrill, J.P., Thorn, G.W., Walter, C.W., Callahan, E.J., 3rd, and Smith, L.H., Jr. 1950. The use of an artificial kidney. I. Technique. J. Clin. Invest. 29:412-424.

61. Merrill, J.P., Smith, S., 3rd, Callahan, E.J., 3rd, and Thorn, G.W. 1950. The use of an artificial kidney. II. Clinical experience. J. Clin. Invest. 29:425-438.

62. Schmid, H.J., Jackson, D.P., and Conley, C.L. 1962. Mechanism of action of thrombin on platelets. J. Clin. Invest. 41:543-553.

63. Coburn, R.F., Blakemore, W.S., and Forster, R.E. 1963. Endogenous carbon monoxide production in man. J. Clin. Invest. 42:1172-1178.

64. Atwood, R.P., and Kass, E.H. 1964. Relationship of body temperature to the lethal action of bacterial endotoxin. J. Clin. Invest. 43:151-169.

65. Nathan, D.G., Schupak, E., Stohlman, F., Jr., and Merrill, J.P. 1964. Erythropoiesis in anephric man. J. Clin. Invest. 43:2158-2165.

66. Tan, E.M., Schur, P.H., Carr, R.I., and Kunkel, H.G. 1966. Deoxybonucleic acid (DNA) and antibodies to DNA in the serum of patients with systemic lupus erythematosus. J. Clin. Invest. 45:1732-1740.

67. Owen, O.E., et al. 1967. Brain metabolism during fasting. J. Clin. Invest. 46:1589-1595.

68. Weed, R.I., Lacelle, P.L., and Merrill, E.W. 1969. Metabolic dependence of red cell deformability. J. Clin. Invest. 48:795-809.

69. Siiteri, P.K., and Wilson, J.D. 1970. Dihydrotestosterone in prostatic hypertrophy. I. The formation and content of dihydrotestosterone in the hypertrophic prostate of man. J. Clin. Invest. 49:1737-1745

70. Goldstein, J.L., Hazzard, W.R., Schrott, H.G., Bierman, E.L., and Motulsky, A.G. 1973. Hyperlipidemia in coronary heart disease. I. Lipid levels in 500 survivors of myocardial infarction. J. Clin. Invest. 52:1533-1543

71. Goldstein, J.L., Schrott, H.G., Hazzard, W.R., Bierman, E.L., and Motulsky, A.G. 1973. Hyperlipidemia in coronary heart disease. II. Genetic analysis of lipid levels in 176 families and delineation of a new inherited disorder, combined hyperlipidemia. J. Clin. Invest. 52:1544-1568.

72. Hazzard, W.R., Goldstein, J.L., Schrott, M.G., Motulsky, A.G., and Bierman, E.L. 1973. Hyperlipidemia in coronary heart disease. III. Evaluation of lipoprotein phenotypes of 156 genetically defined survivors of myocardial infarction. J. Clin. Invest. 52:1569-1577.

73. Rudman, D., Patterson, J.H., and Gibbas, D.L. 1973. Responsiveness of growth hormone-deficient children to human growth hormone. Effect of replacement therapy for one year. J. Clin. Invest. 52:1108-1112.

74. Roth, G.J., and Majerus, P.W. 1975. The mechanism of the effect of aspirin on human platelets. I. Acetylation of a particulate fraction protein. J. Clin. Invest. 56:624-632.

75. Tramont, E.C. 1977. Inhibition of adherence of Neisseria gonorrhoeae by human genital secretions. J. Clin. Invest. 59:117-124.

76. Hebbel, R.P., et al. 1980. Abnormal adherence of sickle erythrocytes to cultured vascular endothelium: possible mechanism for microvascular occlusion in sickle cell disease. J. Clin. Invest. 65:154-160.

77. Mears, J.G., et al. 1981. Sickle gene. Its origin and diffusion from West Africa. J. Clin. Invest. 68:606-610.

78. Knowles, M., Gatzy, J., and Boucher, R. 1983. Relative ion permeability of normal and cystic fibrosis nasal epithelium. J. Clin. Invest. 71:1410-1417.

79. Paller, M.S., Hoidal, J.R., and Ferris, T.F. 1984. Oxygen free radicals in ischemic acute renal failure in the rat. J. Clin. Invest. 74:1156-1164.

80. Curtiss, L.K., Black, A.S., Takagi, Y., and Plow, E.F. 1987. New mechanism for foam cell generation in atherosclerotic lesions. J. Clin. Invest. 80:367-373.

81. Bolli, R., Patel, B.S., Jeroudi, M.O., Lai, E.K., and McCay, P.B. 1988. Demonstration of free radical generation in "stunned" myocardium of intact dogs with the use of the spin trap alpha-phenyl n-tert-butyl nitrone. J. Clin. Invest. 82:476-485.

82. Savill, J.S., et al. 1989. Macrophage phagocytosis of aging neutrophils in inflammation. Programmed cell death in the neutrophil leads to its recognition by macrophages. J. Clin. Invest. 83:865-875.

83. Stratford-Perricaudet, L.D., Makeh, I., Perricaudet, M., and Briand, P. 1992. Widespread long-term gene transfer to mouse skeletal muscles and heart. J. Clin. Invest. 90:626-630.

84. Ishibashi, S., et al. 1993. Hypercholesterolemia in low density lipoprotein receptor knockout mice and its reversal by adenovirus-mediated gene delivery. J. Clin. Invest. 92:883-893.

85. Zhang, S.H., Reddick, R.L., Piedrahita, J.A., and Maeda, N. 1992. Spontaneous hypercholesterolemia and arterial lesions in mice lacking apolipoprotein E. Science. 258:468-471.

86. Gottlieb, R.A., Burleson, K.O., Kloner, R.A., Babior, B.M., and Engler, R.L. 1994. Reperfusion injury induces apoptosis in rabbit cardiomyocytes. J. Clin. Invest. 94:1621-1628.

87. Haynes, W.G., Morgan, D.A., Walsh, S.A., Mark, A.L., and Sivitz, W.I. 1997. Receptor-mediated regional sympathetic nerve activation by leptin. J. Clin. Invest. 100:270-278.

88. Makino, S., et al. 1999. Cardiomyocytes can be generated from marrow stromal cells in vitro. J. Clin. Invest. 103:697-705

89. Jackson, K.A., et al. 2001. Regeneration of ischemic cardiac muscle and vascular endothelium by adult stem cells. J. Clin. Invest. 107:1395-1402.

90. Petersen, K.F., et al. 2002. Leptin reverses insulin resistance and hepatic steatosis in patients with severe lipodystrophy. J. Clin. Invest. 109:1345-1350. doi:10.1172/JCI200215001

91. Weisberg, S.P., et al. 2003. Obesity is associated with macrophage accumulation in adipose tissue. J. Clin. Invest. 112:1796-1808. doi:10.1172/JCI200319246.

92. Xu, H., et al. 2003. Chronic inflammation in fat plays a crucial role in the development of obesity-related insulin resistance. J. Clin. Invest. 112:1821-1830. doi:10.1172/JCI200319451. 